\title{
CERTAIN SPECIFICS IN THE STRUCTURAL POSITION AND THE MODUS OPERANDI OF THE ORGANIZED CRIMINAL GROUPS IN REPUBLIC OF MACEDONIA
}

\author{
Marjan Nikolovski, PhD \\ Faculty of Security-Skopje \\ E-mail: mnikolovski@fb.uklo.edu.mk
}

\begin{abstract}
The organized and serious crime a serious socio-negative phenomenon, which threatens the security of the country, the economy, the rule of law, democracy and endangering the basic and essential human rights and freedoms established by the Constitution as the highest legal act of the state. The organized and serious crime is dynamic, flexible, includes a variety of forms of organized criminal activity and association with legitimate businesses. The organized crime groups are characterized by loose structure, adapting to new requirements and participating in that form of organized crime that is current at the moment and brings the greatest profits. Unlike the organized criminal groups in the wider international community who specialize and perform only one of the forms of organized crime in the country organized criminals easily fluctuate and are involved in various forms of organized crime, subject to availability and needs someone of high-quality forms of organized crime.
\end{abstract}

Keywords: modus operandi, organized criminal groups, forms of organized crime 


\section{Seccurity}

\section{Introduction}

The problem of the organized crime in the Republic of Macedonia in the past 26 years since its independence is a subject of interest of the scientific and professional public. There are several phases in the emergence and the modus operandi of the organized criminal groups. In the last decade of the previous century it was evident the denial and the ignorance by the state organs, through shy and modest appearance of themes referring to the organized crime and the organized criminal groups in the Republic of Macedonia. In the scientific literature can often be seen contents under the title '/s there an organized crime in Republic of Macedonia?', with vague standards that directs to the elements of that type of criminal activity. At the end of the previous century the awareness for the dangers of the modus operandi of the organized criminal groups had strengthen. More and more, the organized crime becomes a challenge and a field of interest of many theoreticians that investigate this socio-negative phenomenon. The pointing at the necessity for changes in the legal-normative sphere would make conditions for dealing with the sophisticated ways of committing criminal acts from the area of the organized crime by the organized criminal groups.

The conditions that led to the emergence and development of the organized criminal groups can be located in the radical changes in the area of the political, economic and security system. In the autocratic, totalitarian and undemocratic systems the organized crime cannot be developed in the same manner and to the extent that today we meet in the developed democratic countries. After the independence of the Republic of Macedonia and the changes primarily in the economy system by introducing the market economy, the political pluralism, the parliamentary democracy, but also such radical changes at the same time are an essential condition for the emergence and development of the organized criminal groups, which is particularly evident for the former socialistic countries such as the Republic of Macedonia. The liberalization of the visa regime, the free flow of people and goods, skillfully was used by the members of the organized criminal groups to carry out high profitable forms of crime in several countries in cooperation with the other transnational organized crime groups.

That period of transition is accompanied by expansion of crime, action of organized crime groups, certain forms that first occur in this region. Of course in addition to the action of the organized criminal groups is the unfavorable economic, the political and the security situation in the neighboring countries followed by the acts of 


\section{Seccurity}

war, the economic sanctions from the International Community to certain countries of our environment, tolerating the actions of some criminal groups of its profits and infiltrate legal financial system which enables the survival of the system in such crises.

One of the ways of the subsistence of the organized criminal groups is through corruption of certain individuals from the political life that have an influence in the functioning of the institutions, how they have been avoiding the investigations against the members of the organized crime groups and their release from criminal prosecution. Members of organized criminal groups who try to corrupt officials at lower levels, how enable its safe environment for a variety of criminal activities, they represent less of a threat in terms of organized crime groups dealing with the impact of the senior executives of the institutions responsible for tackling crime (police, justice officials, politicians and official government representatives).

\section{Organized criminal groups}

'The organized criminal' is very important term that has become part of the dictionary of many scientific workers, politicians, and of the general public. It is very often used without a clear referent point and actually it is very unspecific and unclear. 247 This lack of clarity also influences on the relevant academic debates.

In the world literature can be found hundreds of definitions for the organized crime and the organized criminal groups, from authors 248249250 of various provenance and different areas. However, the emergence of the organized crime doesn't date back so close. Organized criminal groups have existed in the middle Ages (in the 17th century gangs have attacked major cities). The criminal organizations with a broad action

\footnotetext{
247 Michael Woodiwiss and Dick Hobbs, 'Organized evil and the Atlantic Alliance: moral panics and the rhetoric of organized crime policing in America and Britain', Bo British Journal of Criminology, Vol. 49, 2009, pp. 106-128

${ }^{248}$ Abadinsky, Howard, Organized Crime, Third Edition, Nelson-Hall, Chicago, 1990

249 Allan Castle, 'Transnational organized crime and international security', Institute ofInternational Relations, University of British Columbia, Working Paper No. 19

250 Frank E. Hagan,' "Organized Crime" and "organized crime": indeterminate problems of definition', in Trends in Organized Crime, Vol. 9, No. 4, 2006,
} 
spread, their transition from local to national and even on international scale, are connected to the monopoly and the financial aristocracy. ${ }^{251}$

The defining of the organized crime, ie the organized criminal groups in the country, is performed by the Law on Police ${ }^{252}$ and the Law on Public Prosecution of the Republic Macedonia. ${ }^{253}$

The geostrategic position of the Republic of Macedonia, as well as the social, the political, the security and the economic conditions allow the emergence and activity of organized criminal groups. Macedonia is located in the central part of the Balkan Peninsula, a crossroads of the main east-west and north-south resulting in increased flow and circulation of passengers, which in turn has an impact on transit and transport of illegal goods, mainly to drugs, in recent years, fueling hostilities in the Middle East and an increased number of refugees and migrants transiting through the country.

The different levels of economic development in the neighboring countries and in general in the region, the non-compliance of the fiscal policy, the big differences in the prices of certain goods in the countries in the region, mostly in the neighboring countries, stimulates the smuggling of goods and the activities of organized criminal groups these regions.

The second trait is the kinship, friendly, ethnic, labor and other ties with the Diaspora in the Western European countries facilitate the movement and actions of the members of the organized criminal groups, providing logistical and financial support from the countries of Western Europe as a destination. Such characteristics affect positively the modus operandi of organized criminal groups, facilitates crime and as a means of transport, places of storage, and cause unfair market competition. By avoiding paying taxes to the state, the members of the organized criminal groups lead to unfair competition in relation to goods brought into the country with all taxes paid.

The unfavorable condition in the judicial system is also in favor of the action of the organized criminal groups. The incomplete implementation of the legislation by the judicial authorities especially by not implementing the measure of confiscation of property, when it is evident a disproportion between the current assets and legally revenues for those members of organized criminal groups, thus the members of

\footnotetext{
${ }^{251}$ Milutinovic M. (1967). "Criminology, Eeograd, 58

252 Official Journal Republic of Macedonia No.33/15

253 Official Journal Republic of Macedonia No.150/12
} 
organized criminal groups and it provides easy to update the links in criminal circles and to continue with criminal activities.

\section{Organization, structure and modus operandi of the organized criminal groups in the Republic of Macedonia}

The reasons, the factors and the conditions for the emergence and development of the organized criminal groups in different countries are different, so from that perspective we can talk about specifics and difference in modus operandi of the organized criminal groups in different countries. Specifically for Macedonia, since its establishment as an independent and sovereign state today can be stated the following conditions for the emergence and development activity of organized criminal groups: 254

- Non-established ethic elite that is condition sine quanon of the political elite in the democratic and legal state;

- Inconsistent principle of separation of powers in the non unique system of the state government in Macedonia, where the absence of a system of legal mechanisms and procedures for mutual 'control and balance between the institutions responsible for law implementing. The consequences are lack of law governing manifested by halting or selective enforcement laws, failure of the legal institutions, which somehow skillfully used by members of the organized criminal groups to perform highly profitable s criminal acts of organized crime and corruption;

- Lack of optimal independent institutions;

- Poor legal framework;

- Vague and inconsistent systems of the privatization process, public procurement, government concessions, financial management and control of the budget and public funds;

- Too many laws and regulations which are inconsistent and contradictory governing administrative and legal matters, allowing too much discretion in deciding civil servants;

\footnotetext{
254 Labovic M. Nikolovski M "Organized crime and corruption", Faculty of security -Skopje , 2010, side. 45
} 
- Low paid civil servants and served unprotected authorized persons responsible for detecting and proving the action of organized criminal groups.

What characterizes the organized criminal groups in Macedonia is their involvement in several highly profitable forms of organized crime such as drug trafficking, migrant smuggling, violent and serious crime on a national and international level. From analyzes that have been made about the characteristics of organized criminal groups by the Ministry of Interior of the Republic of Macedonia, they are the following features: ${ }^{255}$

- The organized criminal groups polycriminal and operating in more than one area of crime;

- The connections between the members of the organized crime groups are often based on family or friendship relationship;

- over 50\% of organized criminal groups are of medium size which is comprised of 5-14 members;

- the acquired funds from criminal activities are laundered through investments in financial markets, in legitimate businesses, movable and immovable property;

- the dominant mode of operation using the corruption in their criminal activity, which is especially pronounced among officials in law enforcement from lower levels and influence in trials of their members to protect against criminal prosecution.

\section{Size of the organized criminal groups}

As for the size or the number of members of the organized criminal groups dominate small groups of 3 to $15-20$ members. According to official reports of the Ministry of Internal Affairs, there are 6 groups out of ten with few members (from three to twenty people), while there are three groups consisting of 20 to 50 people and only one group that consists of 50 to 100 people. According to the size of the organized criminal group they are different from other countries especially ones where dominate

\footnotetext{
${ }^{255}$ Threat Assessment of activities organized and serious crime, the Ministry of Interior of the Republic of Macedonia, Skopje, 2016
} 


\section{Securiagues}

organized criminal groups like mafia organized crime groups, where we talk about groups with greater numbers of members before, and other differences in the way of

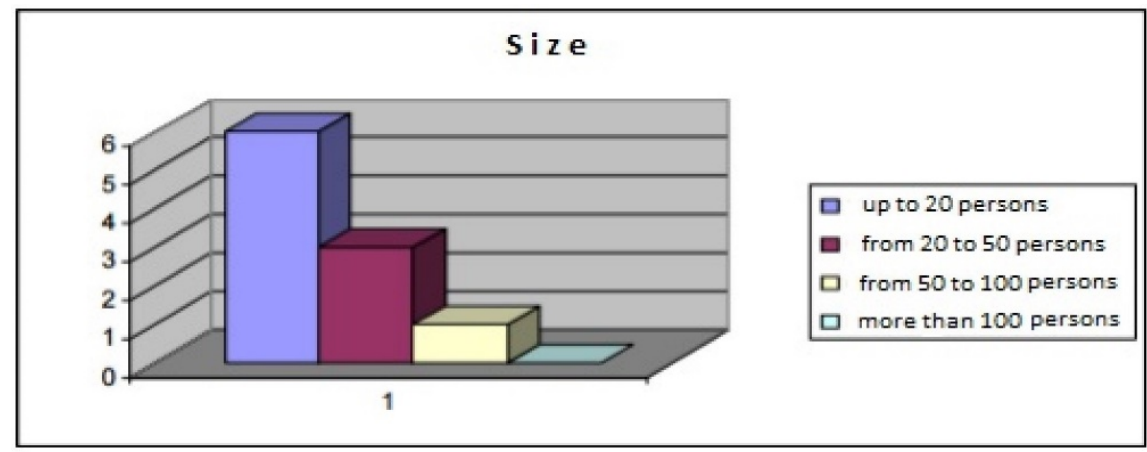

Figure 1: Size of the organized criminal groups

structuring, action and so on. The mall organized criminal groups in Macedonian easily adapt to the new conditions primarily political, economic, security and infiltrate the system how through corruption fail to realize their criminal activities and thereby avoid being detected and sanctioned.

\section{Trans-sanction}

The level of cross-border operations, i.e. the trans-nationality of organized crime groups are medium-high, and half of the groups have operations in three or four countries, and the other half of the groups have operations in five or more countries, which means that these groups are quite active in the region and beyond. Civen the fact that the criminal activity of members of organized crime groups prefer territory of more than one country, met the criteria for trans-sanction talk about organized crime. The location of the Republic of Macedonia as a central Balkan country where cross busy intersections of activity of organized criminal groups trans-sanction affect connectivity and support the criminal activities of the organized criminal groups from Macedonia and foremost neighboring countries. What is distinctive about the activity of the organized criminal groups in the Republic of Macedonia is the logistical support they receive in Western Europe through their family and friendly ties that live in these countries as a destination of the operation of the organized criminal groups. 


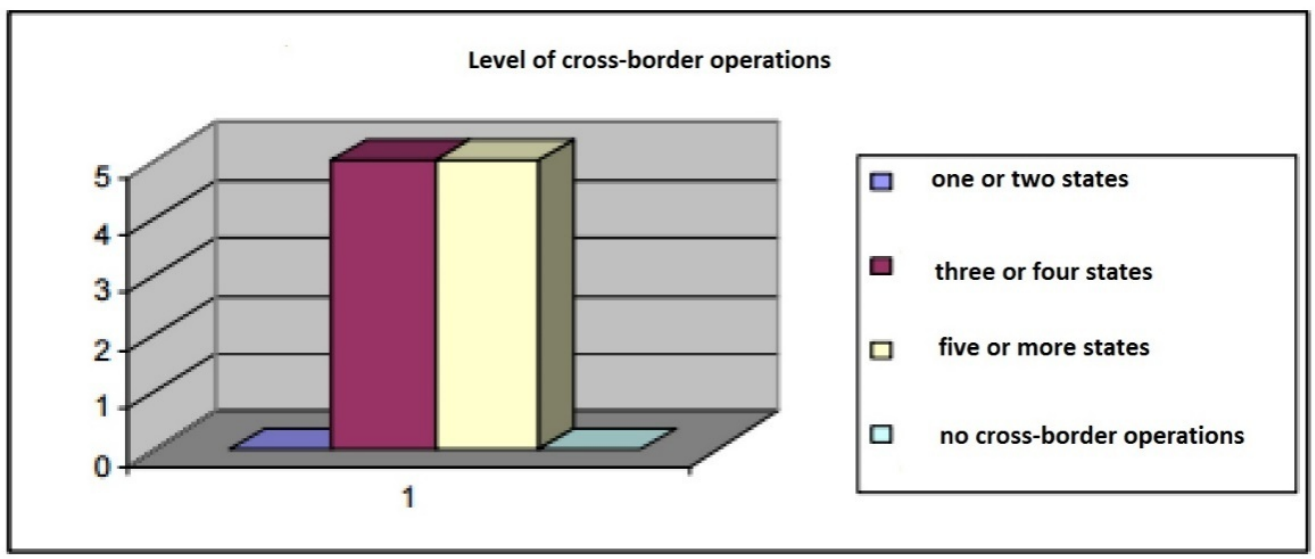

Figure 2: Level of the cross-border operations

The dominant areas of the criminal activities are the illegal drug trade, the violent and serious crime, migrants smuggling (which is very often in the past years along with the intensified military actions in the Middle East especially in Syria). The founders of the organized criminal groups remain active within the groups and rarely are changed. Evident are that kind of organized crime groups that are based solely on short-criminal interests and have no continuity in carrying out criminal activities.

Unlike the strong solidarity integrity of the organized criminal mafia-type who are characteristic in the other countries, the organized criminal groups in the Republic of Macedonia are characterized by loose association of members which is especially characteristic for the economic and financial crimes, the structure is characterized on the basis of family friendly basis and criminal interests, which is especially evident in the top of the structure for organized criminal groups that operate longer period. The criminal interest links the members of the group and provides continuity of the operation for extended periods of the organized criminal group. The most common form of organization are the criminal networks, in which the perpetrators have important individual roles, and they are often associated with a particular function or power.

For the criminal activity of the organized criminal group to run without any particular difficulty, the members of the organized criminal group in its composition include individuals from the state institutions, primarily the police, the prosecution and the court. Such individuals in certain situations are "accomplices" and above "advisors" and help the organization in the way it should act with their authority and power act 
and other primarily inspection services for not taking appropriate measures against members of certain organized criminal groups. These organized criminal groups have personal structure and professionalism and depending on the field of criminal act vary according to the number, the material condition, the specifics in the way of action. The organizer or leader of the organized criminal groups to devise and assigns roles responsible for the organization, finding tools and methods (finding connections with law executors).

The identity of the organized criminal group is mainly connected to ethnic grounds or family basis and is organized by people from the same ethnic group. Thus, 6 groups have been organized, while the remaining 4 groups are connected to the social base where people have close social interests and social status.

The family relationship is found among those organized criminal groups involved in trafficking drugs, primarily heroin. The family relationship appears as an aggravating circumstance when it comes to discovering the most profitable form of organized crime. On the one hand it is almost impossible to select a face-member of the organized criminal group and to be convinced to work for the interest of the investigators, on the other hand it is also almost impossible to infiltrate undercover police spies into the composition of that type organized criminal groups.



Figure 3: Identity

The ethnic belonging of the members of the organized criminal group provides homogeneity of the group which is especially expressed among those organized 


\section{Securiagues}

criminal groups that are specialized in executing acts connected to illicit drug trafficking (marihuana, heroin and cocaine).

The level of violence among the organized criminal groups is very low, or eight of the groups do not practice or practice very little violence and there is one group that occasionally uses violence and one group that regularly uses violence in its criminal activities. So, it can be concluded that the organized criminal groups in the Republic of Macedonia are groups that mainly don't want to attract attention and don't use violence publically compared to Bulgaria, where organized criminal groups are also nonviolent according to Europo ${ }^{256}$ which means that act upon sophisticated and covert. Nonviolent action of organized criminal groups is particularly characteristic those organized crime groups involved in economic and financial crimes, which are represented in the country in a high percentage compared to other forms of organized crime.,

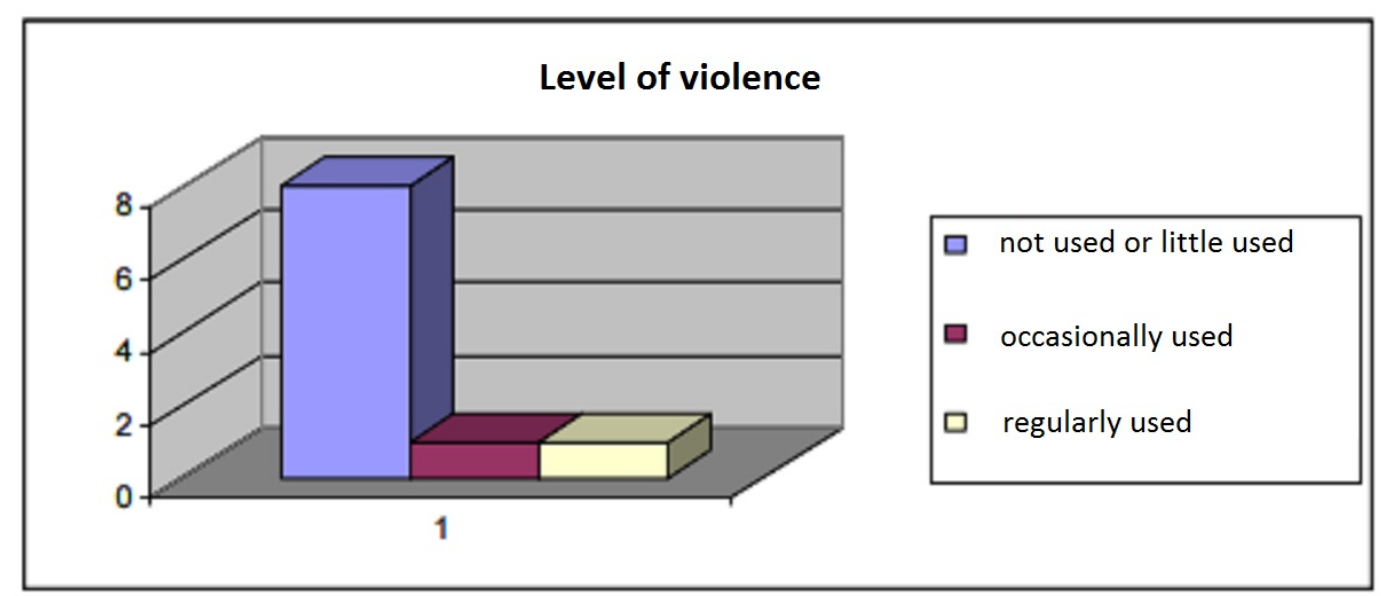

Figure 4: The level of violence

The entering in the legal economy of the organized criminal groups in the country according to the Ministry of Interior is relatively large. Only three groups have no activities or they are very small, while there are four groups that have made investments in the lawful activities and three groups repeatedly has tangled legal and illegal activities.

${ }^{256}$ EUROPOL, OCTA 2009, EU Organised crime threat assessment : www.europol.europa.eu 


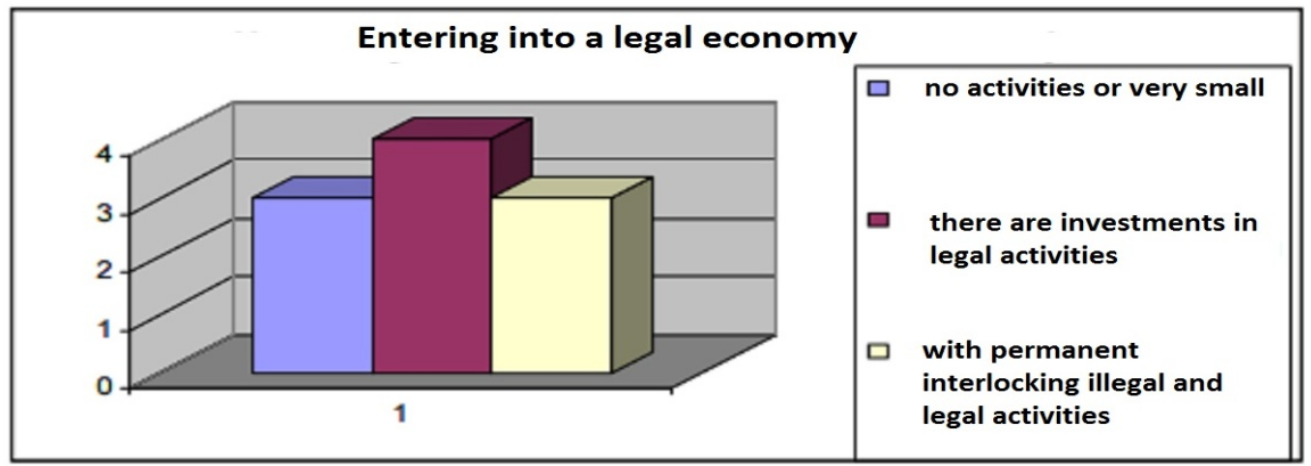

Figure 5: Entering in the legal economy

According to the type of the criminal areas that are involved ${ }^{257}$ in $43 \%$ of the organized criminal groups are involved in only one criminal area, $26 \%$ of the organized criminal groups are poly-criminal and act in more criminal areas, $20 \%$ are oriented to one are but in certain circumstances expand its criminal activity to other criminal activities, $11 \%$ have no identified areas of their criminal activity.

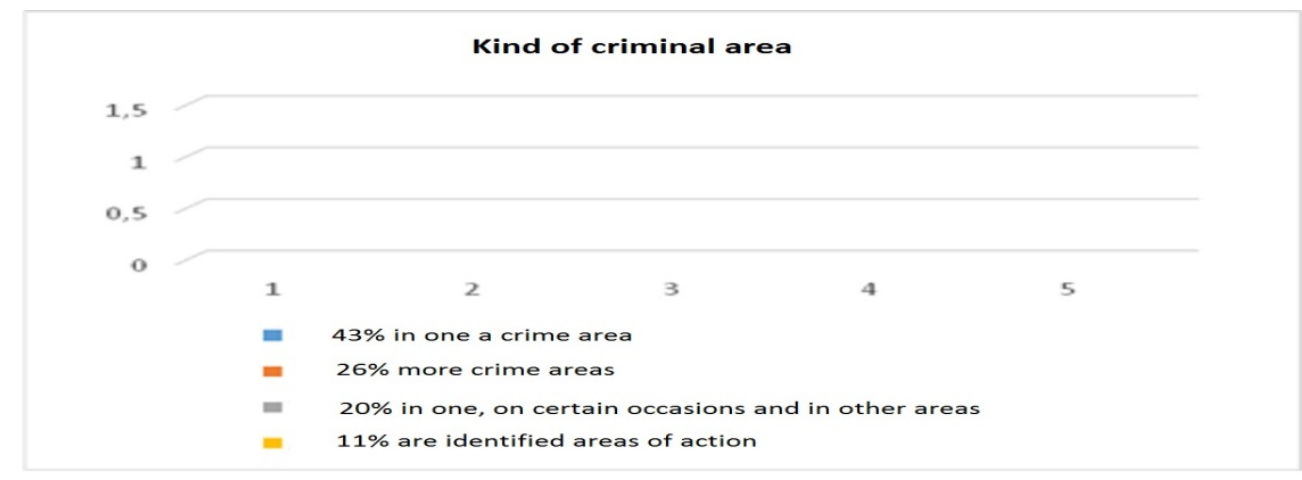

Graphic display of the type of the criminal area of activity of the organized criminal groups

After achieving greater amount of illegally gained capital that capital then is by laundering infiltrated in the the legal financial system in many ways. In the first phase,

${ }^{257}$ Threat Assessment of activities organized and serious crime, the Ministry of Interior of the Republic of Macedonia, Skopje, 2016, pg.. 15 


\section{Seccurity}

there is a switch of the huge financial resources to the of-shore regions and then these funds are returned as foreign investment in the country. Through individuals, foreign nationals, mostly from Cyprus (man-firm employee) that money occur as a foreign investment with redemption of dominant shares in the companies and thus become dominant owners. As foreign investment they are subsidized by the government institutions and certain tax breaks and actually work as members of organized criminal groups which money acquired illegally by running high-profitable forms of organized crime, so the dirty capital that previously was put forward in abroad, the same returns as foreign investment and carried its infiltration into legal businesses say in the legal financial flows of institutions.

The legal business is just one of the ways, used for increasing of the financial power. Most of the legal businesses opened by the members of the organized criminal groups usually are in the areas of transport, and they are used for smuggling illegal goods. The organizers and the members of the organized criminal groups within the legal subjects act as founders and managers of many legal subjects through which is performed the payment of funds in order to be concealed the true origin and persons who are part of the management team with a dominant role in the decision-making . The goal is overflow of the capital from one to another legal business for acquiring capital. The money they will earn from these kind of activities, especially on international level, allow the members of the organized criminal groups to become financially powerful.

The most famous areas for investment of this money are real estate, investments in the of-shore zones, the establishment of phantom companies and industries. As examples of venture money are listed apartments, hotels, casinos, factories, sports clubs, and restaurants.

However, that property usually does not take the name of the real owner, but some family members or close friends. The members of organized criminal groups get protection from the criminal activities provide direct meetings in concluding criminal acts import and use of methods of providing routes of transport for smuggling goods. What is massive in the modus operandi among the members of the organized criminal groups in this area is the use of dual citizenship or they have citizenship from the mother country Republic of Macedonia and citizenship from Bulgaria, which allows them free movement in the countries of West Europe, where they are registered as as 
perpetrators of crimes and have been banned from entering the passport from the Republic of Macedonia.

The control of the area of action is not a characteristic for most organized crime groups, but exceptions are those involved in drug trafficking and abuse of official position and authority. The organized criminal groups involved in drug trafficking as a form of organized crime, have a high control of the drug market, while those which are involved in crimes related to abuse of power and authority are active corruption offenses bribery and receiving rewards for issuing work permits and monopoly in the operation provides through political influence of the leaders.

\section{Field of activity of the organized criminal groups}

If we make an analysis of the data for the realized criminal acts from the area of the organized crime in the past few years, we can conclude that since few years ago the dominant form of acting of the organized criminal groups was the illicit drug trade. According to the Yearly report ${ }^{258}$ of the Ministry of interior for 2009 in the drugbusiness the most frequent are the Albanian criminal groups from Macedonia connected to the criminal structures from Turkey from where they supplied heroin and criminal structures of the same ethnicity residing in Western Europe, which is confirmed by statistics, or out of 42 criminal suspects persons - citizens of the Republic of Macedonia, 38 persons were of Albanian ethnic origin. Activities in the area of combating illicit trafficking (HT) drug were aimed at gathering information on criminal groups from Macedonia who act in the area of North-West Macedonia and establish their links with the people of the Republic of Turkey, where the acquires drug heroin as well as their links with criminal structures of Western European countries, ie cutting the Balkan drugs route, which is crossed eight international channels NT heroin.

In the last years a dominant form of acting of the organized criminal groups is the smuggling of migrants. The intensity of the irregular migrations toward the westBalkan's route in 2015 according to the previous years has changed and evolved according to the origin countries of the migrants, the number of registered migrants,

\footnotetext{
${ }^{258}$ Annual report of the Ministry of Interior for 2009 y.. Public Security Bureau, Central Police Services Department for Organized Crime, Department of Criminal Intelligence Analysis, 2010
} 


\section{Seccurity}

the structure of the persons transiting, and according the way of transiting countries. During 2015 the number of migrants transiting along the Western Balkan route has rapidly increased by economically migrants and migrants coming from the war areas. Such a state of new supply form of organized crime had its affection in the actions of the organized criminal groups in the region. They cooperated with organized criminal groups in the neighboring countries have frequent changes of members and their roles are formed and ad hoc criminal groups of mixed composition with nationals from countries in the region and members of the countries of origin of migrants and people with criminal background intermediaries and providers of various services. Of more frequent occurrence is registered to a part of the organized criminal groups in $R$. Macedonia is involved in the trafficking of migrants include nationals mainly from Greece, Bulgaria and Albania.

For individual services the organized criminal groups use the local population in the border area (guides, drivers and other staff who are responsible for providing security and accommodation), engaged when needed and often changed. In the executing of certain activities the members of the organized criminal groups include the migrants who don't have enough financial means to pay the services. The activities of the organized criminal groups are aimed toward organizing transfer and accommodation, providing falsified documents for entering the countries from the European Union. For migrant's transfer from Greece, through Macedonia to Serbia they charge from 300 to 1500 Euros per person according to the way of transport, the quality of the accommodation and other services. The money are usually paid in advance to a person in one of the larger cities in Greece and sometimes directly to the driver or the legal entity which is a vanguard of the vehicle transporting migrants. ${ }^{259}$

The structure of the organized criminal groups is clearly hierarchical. Those are homogenous groups that have strong and long-lasting core of key people surrounded with a circle of very few permanent members. What connects them and makes the collaboration between the members of the organized criminal groups are the ethnic belonging, the friendship and the family ties, the lack of language barriers and most common the common criminal record from the past. One of the common characteristics of the members of the organized criminal groups is their attempt to change the identity and use of forged documents, and the use of the benefits of dual

${ }^{259}$ Regional threat of severe and organized crime, Skopje, 2015 


\section{Seccurity}

citizenship as a means by which to facilitate the movement and execution of crimes in other countries.

Typical for the work of the organized criminal groups is the occasional inclusion of people who have no criminal record, mainly for logistical needs, and individuals specialized in specific areas. To secure information exchange, the organized criminal groups use sophisticated means of communication, and more frequent and direct communication and transmission of messages through couriers.

\section{Conclusion}

Today we face a serious and organized crime which is constantly developing new forms of manifestation, primarily depending on the global change, the technological progress and the social development. One of the prerequisites for entry of the Republic of Macedonia in the European Union is undertaking complex activities and intensive work, which primarily takes place in the efficient fight against the serious and organized crime.

The organized criminal groups in the country are and in the future will be a serious threat to the citizens' security. The structure of the organized criminal groups will continue to be changed in terms of its heterogeneous composition will include members from different nationalities as special mark thereon. A feature of the organized criminal groups in relation to the criminal matters is their poly-criminality which means they will be involving in areas of criminal activity that currently carries greater profits.

In certain areas of criminal activity, the organized criminal groups strengthen their relationships internationally in order to facilitate criminal activities outside the Republic of Macedonia, especially in the area of drug trafficking and smuggling migrants, forms that dominate as a subject of interest in the past years.

A feature of the organized criminal groups is their structuring and formation of smaller structures which are associated with similar criminal organizations from the region, so that the fight against the serious and organized crime cannot be reduced to national borders. Therefore, the process of gathering evidence needed to prosecute the members of the organized criminal groups who has committed such crimes as well as confiscation of property acquired through crime, is very complex. Certain organized 
criminal groups perform their criminal activities exclusively outside of their domicile countries; therefore, it is necessary strengthening of the cooperation between the countries and the agencies of the European Union with the police and other law enforcement agencies in the region, in order to create space security in the whole region, and therefore the European Union.

\section{Bibliography:}

1. Abadinsky, Howard, Organized Crime, Third Edition, Nelson-Hall, Chicago, 1990;

2. Allan Castle, "Transnational organized crime and international security", Institute of nternational Relations, University of British Columbia, Working Paper No. 19, 1997

3. Frank E. Hagan, "Organized Crime and organized crime: indeterminate problems of definition", in Trends in Organized Crime, Vol. 9, No. 4, 2006,

4. Milutinovic M. (1967). "Criminology, Beograd, 58

5. Michael Woodiwiss and Dick Hobbs, "Organized evil and the Atlantic Alliance: moral panics and the rhetoric of organized crime policing in America and Britain", British Journal of Criminology

6. Labovic M. Nikolovski M "Organized crime and corruption ", Faculty of security -Skopje , 2010,

7. "United Nations Convention against Transnational Organized Crime", Palermo, 12-15 December 2000.

8. Threat Assessment of activities organized and serious crime, the Ministry of Interior of the Republic of Macedonia, Skopje, 2016

9. Annual report of the Ministry of Interior for 2009 y.. Public Security Bureau, Central Police Services Department for Organized Crime, Department of Criminal Intelligence Analysis, 2010

10. Regional threat of severe and organized crime, Skopje, 2015

11. EUROPOL, OCTA 2009, EU Organised crime threat assessment : www.europol.europa.eu

12. Official Journal Republic of Macedonia No.150/12

13. Official Journal Republic of Macedonia No.33/15 